\title{
Orientalism and Muslim Historical Critical Methods
}

\author{
Sajid Shahbaz Khan \\ (Sajid Hameed), Associate Professor \\ University of Central Punjab, Lahore
}

$\mathrm{PhD}$ Scholar, University of Management

and Technology, Lahore, Pakistan

\begin{abstract}
Apart from the orientalists ignorance, bias and grudges, there is a very basic academic reason which takes them away from the position that Muslims hold in the study of Islam and Islamic Civilization, even if they try hard to be objective in their studies. That reason, in its core, is epistemic.

Muslims were forced to believe only in the truth. For that, they devised methods to determine the truthfulness of knowledge. In this article, I particularly discussed the methods with which they studied the authenticity of a transmitted knowledge; historicity. Two methods of transmission are discussed; Tawātur and Khabr al-Wāhid. What these concepts are and how they are helpful in determining the truthfulness of knowledge are explained. How tawātur provides absolute knowledge, while khabr al-wāhid does not. These methods are named as Muslim Historical Critical Methods for better understanding. Orientalists rejected many authentic contents of Islam because they were ignorant of these methods. Therefore, their rejections are sometime too absurd for Muslims to believe in the objectivity of their research.
\end{abstract}

Keywords: Historicity, Modes of transmission, Tawātur, Khabr al-Wahid

\section{Introduction}

The Orientalists attacked the teachings and history of Islam, biography and character of the Holy Prophet, and the historicity of primary sources of Islam. The content of the Holy Quran and Hadith was attacked as well on the basis of Historical Critical Method, especially in the literature written after $1600 \mathrm{CE}$. Historical criticism is the examination of any text/account of event in the light of the historical knowledge without being fettered by religious prejudices.

After a careful study of the work done by orientalists, I came to a conclusion that apart from their ignorance, biases and grudges, there is a very basic academic reason which takes them away from the position that Muslims hold about the above mentioned areas of study, even if they try hard to be objective in their studies. That reason, in its core, is epistemic. I mean;

- How a proposition becomes knowledge or truth?

- How any information transmitted to us would be identified as authentic or unauthentic?

In this article, my focus will be on the second question. I will try to explain Muslim scholars' position regarding authenticity of transmitted information through history. 


\section{Methods of Identifying the Truth}

Muslims from the very first day were put into a test of accepting the truth instead of following their own superstitions or those of their fore-fathers, ${ }^{1}$ and the false attribution of any commandment to God was considered a serious sin against Him ${ }^{2}$ I mean a sin having very serious consequences. ${ }^{3}$ Attributing a lie to the Holy Prophet was not of less consequence. ${ }^{4}$ This Qur'ānic demand and sinfulness of such fabrication forced them to be careful in accepting any information attributed to God and the Holy Prophet. This cautiousness made them study the phenomena of transmission of information from generation to generation, and invent tools and methods to examine the historical accounts critically. This effort resulted into a scientific system for determining the historicity of anything; we may name it Muslim Historical Critical Method. This science has been developing through centuries, leaving many things settled and others disputed until now, and dividing Muslim academicians into a few schools; Zāhirī, Muhadithīn, Usūliȳin, Mu'tazila and Shī ah, etc. This Muslim historical criticism is divided into two major parts:

- Riwāyah: [Arabic: الرواية] determining the validity of attribution of any proposition to God or The Prophet.

- Dirāyah: [Arabic: الدراية] Examining the content of information critically in the light of five things, explained in the following pages.

\section{Riwāyat}

Riwāyat literally means narration, account, narrative, tale, report, etc. and technically it connotes two kinds of historical reports:

\section{1- Mutawātir}

2- Khabr al-Wāhid

\section{a. Mutawātir: Concurrent Transmissions}

Mutawātir is an adjective from Tawātur which literally means concurrent occurrence with regular gaps. As a term, it means concurrently transmitted. It is explained as a mode of transmission, in which information is transmitted to us in a manner that the number of reporters and means of transmission are so large that the reporters of such number cannot naturally collude to fabricate a lie, and this size of the number of reporters remains similarly large in all generations, from the first generation to the last. This report should be about a phenomena known through the senses rather than intuition or reasoning. In simple words, when a report is reported by a very large number of people about a heard/witnessed words/event, with the same large number of people throughout the generations until our time, is called mutawätir, ${ }^{5}$ i.e., transmitted through the tawätur.

The examples of the mutawatir reports are propositions of that kind: "Muhammad Ali Jinnah is the founder of Pakistan" or "America won her freedom from Great Britain."

These are being reported since the day Pakistan was announced as a new country and America won her freedom. A very large number of people, almost all Pakistanis and Americans, have reported these occurrences to their children. At 
the national level, they are doing the same through the print and electronic media, and annual celebration of their national days. This kind of reported proposition is considered 100 percent true, because it is being verified in many ways. The propositions which are reported by such means are considered directly witnessed facts, even if they happened in the remote past, or even if we have not witnessed them. For instance, Iran is a country which I have never visited but I believe in her existence on the globe just as I believe in my own existence.

However, propositions like: "Universe came into being by big-bang", are not qualified to be called mutawätir, even if this proposition is concurrently being reported by a large number of scientists, teachers, people from all walks of life, in formal and informal conversations, through the media, etc. The reason being, that it is not known by sense experience. The first generation must have known it by their senses. If the proposition is phrased as: "that scientist says that the universe came into being by big-bang," and that is reported by a large number of people and verified through other means, then it would enjoy a status of tawātur, because it would then be known by sense experience.

Propositions with that kind of transmission also provide the same certitude in religious matters, for instance, religious propositions like Muhammad (SAW) belonged to the Arabian Peninsula. He announced himself, like Moses and Jesus, a Messenger of God. He enjoined his people to offer prayers five times daily. The Holy Qur'ān also has the same status of transmission, as a large number of memorizers of the Holy Book are concurrently memorizing it without any gap throughout the centuries, and making their successors memorize it. Muslims recite it in the five daily prayers partially, and thoroughly in the holy month of Ramadān. Apart from that, it is mandatory for Muslims to learn reading and reciting its Arabic text in a perfect manner. The mosques and qāries ${ }^{6}$ provide these services on daily basis. This whole set of phenomena make the Holy Quran, its verses and its order as concurrent as the knowledge of the existence of Iran. Allāmah Shaukān̄ ${ }^{7}$ (died 1250AH) explained the concept of tawātur briefly:

Literally tawātur means coming of the one after the one with an interval between them, it is derived from " $w t r$ ". Technically it is defined as: ...It is a proposition about a witnessed matter, reported by a large number of people, too large to collude to tell a lie, because small number of people may collude or may be forced to fabricate anything. ${ }^{8}$

This historical phenomenon is usually left unnoticed by the orientalists who attacked many mutawātir reports without knowing the reality. For Muslims, the objections of such orientalists appear nonsensical. Unfortunately, the Muslims who defended their position did not present it with sound arguments.

The term, 'tawätur,' is found in the very first book on Islamic Jurisprudence; alRisālah by al-Shaf $\overline{1}^{9}$ who lived 767-820 CE / 150-204 AH. Other similar concepts were mentioned earlier in the books of Shafie's teachers like Imam Mālik ibn Anas (711-795 CE / 93-179 AH), who preferred, "the practices of the people of Medina"10 regarding any other kind of reports. This practice was actually the tawātur in the form of daily acts, as these practices were being acted 
upon by the whole population of Medina, thus providing reliability to such practices. Before Malik, Abu Hanīfah (699 - 767 AD / 80 - 148 AH) was blamed for having rejected a number of Hadiths on the basis of reports received by his generation through tawātur. ${ }^{11}$ This brief history of the early period shows that Muslims discovered this historical phenomenan somewhere during the years 50 to $150 \mathrm{AH}$.

Another term called ijmā (consensus) had the same connotation, but with the passage of time, the tawātur retained its meaning, while ijmā ` evolved into a different concept. ${ }^{12}$ Initially, it was almost a synonym of the tawātur; when all people believed in something or acted collectively. This meant that they were in an unstated agreement or consensus (ijmā'). Ibn 'Abd al-Barr (died 463AH) used this term in the sense of tawātur. He stated the whole idea as follows:

As far as foundations of knowledge in Islam concern, they are the Qur'an and the Sunnah. The Sunnah is divided into two types: first of them is the Sunnah which is transmitted by the whole of the community to the whole of the community, this is the absolute true knowledge, if all witnesses show no disagreement on it, then no question remain regarding its authenticity. The one who rejects this consensus (ijma $\left.\bar{a}^{\prime}\right)$ of the whole of the community, is similar to that who rejects a command of Allah...13

\section{b. Khabr al-Wähid}

This is the second kind of Riwāyat. Khabr al-wāhid means a proposition reported by a small number of people, a number of people who do not attain such quality of the number i.e invulnerability from collusion to tell lies. That number is digitized from 1 to 70 or more. The proposition transmitted by that small number is far lesser in validation than tawātur. Reports by tawātur are $100 \%$ true, while khabr al-wāhid is either true or false. Here the number does not help but the character of the reporter ( $i l m$ al-rijāl) and critical examination (Dirāyat) of the proposition help. It is defined as:

It is a reported proposition which does not has a certitude to be called 'ilm (truth), it does not provide such certitude, neither itself nor with the support of other evidences beyond its text. There is no comparison between this and mutawātir. Majority of scholars hold this position about khabr al-wāhid. ${ }^{14}$

The English synonym for `ilm is knowledge. However, `ilm in this context means truth. When Arabs used the word ilm for any information, they meant authenticity and truth. In the words of the experts of jurisprudence: "tawatur yūjib al-'ilm" and "khabr al-wāhid yüjib al-'aml"; "tawātur passes on truth to us, we are bound to believe in it and khabr al-wāhid transmits to us a probable notion, but it may ordain us to obey without making it a part of our belief."

Belief ( $a q \bar{l} d a h$ ) in Islamic paradigm is a set of absolute truths, supported by strong evidences. It is not a set of superstitions or mere rational conjecture or something based on probable means of transmission. For example, I may state that the proposition "Iran is a country" is a fact; you must believe in that. The mere factuality of the proposition, because of being said tawaturly, require us to believe in it. The proposition; "five time prayer is obligatory" is true, as it is passed on to us through unquestionable mode of transmission. Such state of its 
authentication requires us to believe in it as a fact. But the proposition: "the prophet prohibited tattoos," is passed on to us through khabr al-wähid, which is a probable means. Therefore, whosoever judges it as a statement truly attributed to the Prophet may act accordingly, but because of its nature of transmission it could not be considered as fact. For that concept, jurists use the term zanni (speculative knowledge). When a khabr al-wähid passes two tests ${ }^{15}$ of examination, Muhadithī ${ }^{16}$ consider it a Sahīh Hadith.

It is noteworthy that $a$ Sahīh Hadith is also a zannī peace of information. It does not enjoy the status of a hundred percent truth. Its certitude is scaled between 51 to 99 percent which is a satisfactory level of proof. The information passed on to us through tawätur enjoys the status of a fact.

Imam al-Shaf $\overline{1}$ stated the difference in both types of narrations. He says that mutawätir is authentic in two ways; externally and internally, while khabr alwăhid is authentic externally (like a proposition which is either true or false). He illustrated this with examples, where he wrote that "IIm has a few aspects. One of them is the ilm which covers the truth in both ways, externally and internally. The second kind of 'ilm is that which covers the truth only externally. For example, a judgment given by a judge against a criminal on the basis of two witnesses. Apparently we will consider this judgment true, but it is possible that the defendant may be innocent and the two witnesses are mistaken. This judgment is covering truth only externally but not internally. For the first kind of 'ilm, Muslim epistemologists use the term Qat $\bar{\imath}$ (definitive) and for the second zannī (speculative).

Thus, for being zannī, every Hadith is scrutinized by two kinds of tests. The first test examines the chain of narrators:

Every chain has two elements; people and their relation of being teacher (Hadithteller) and student (Hadith-learner). Therefore, they examine every Hadith, prudently working on questions like are the reporters reliable? Are they considered pious men among their friends and relatives? Are they truthful, honest, and prudent persons? Was their faculty of memory intact when they were reporting Hadiths? Have they met the persons from whom they heard that Hadith or were they were just mentioning them falsely? How old were they when they heard that Hadith? Was that particular student a direct listener to that particular teacher or he heard the Hadith indirectly? A long list of questions was used to determine the reliability of the narrators. If any narration did not pass this test, it was considered invalid ( $z a^{`} \bar{\imath} f$ ), i.e., having no legal force in Islamic sharia and beliefs.

\section{Dirāyat}

The second test is called dirāyat. For this test, every text of Hadith is examined in five different ways:

a. Intellect and Reasoning: every text must not contradict the rational concepts and ideas that humanity has discovered by intuition or deduced intuitively. These are badīhāt; intuitive facts, undoubted realities. The Prophet $(S A W)$, being guided by God the All Knowing, could not tell anything opposing or contrary to the 
reality. Eventually it is said, any Hadith that opposes these facts must be considered false.

b. Qur'ān: the Hadith texts must not be contrary to any teaching or statements of the Holy Qur'ān. The Quran is also transmitted to us through tawātur. Therefore, it is infallible, both in its content and transmission. The content of the Holy Qur'ān, being divine, is free of mistakes. Tawätur proves that it is the same text that was left by the Prophet. Eventually, it contains absolute knowledge, while Hadith does not. Therefore, the Holy Qur'ān is mīzān, a standard against which Hadith should be evaluated.

c. Sunnah Mutawātirah: it means the well-established guidance of the Prophet $(S A W)$, apart from the Holy Qur'ān, passed on to us through tawātur, and consensually, accepted by the whole Muslim community. It is the third criterion for testing any Hadith, this Sunnah is authentic and preserved through tawätur. Like the Holy Qur'ān, it also enjoys the status of being authentic and definite source, for that it can play the role of a criterion for Hadith, which is a speculative and probable. The Hadith must bring forth the material agreeable with that Sunnah. If it contradicts the Sunnah Mutawātirah, it shows that someone other than the Prophet $(S A W)$ has falsely said it, because the Prophet $(S A W)$ does not go astray from the path he himself carved with his daily practices and repeated sayings.

d. Repeated Practices of the Society: it is our fourth criterion for Hadith. We all know that apart from their religious activities, every individual does many things daily. We are used to them, like drinking, eating, cooking, using fire, making tools, talking, showing love to children, building houses, etc. They are our cultural customs, biological needs, mental activities, psychological outcomes, etc. and are very habitual for us as Sunnah in our religious practices is. When a Hadith narrates anything contrary to these kinds of practices, while these are not prohibited in definite sources, this means that the Hadith under examination is falsely attributed to the Holy Prophet $(S A W)$.

e. Empirical Data: it is the fifth and the last criterion for testing a Hadith. It is the rational or empirical data or deduced opinions, which has attained the status of absolute knowledge, and proved by conclusive evidences or proofs. Allamahal-Baghdādī has stated briefly these five criteria in his book Al-Kifāyah. He states that:

Khabr al-wāhid will not be accepted if it opposes rulings of reason, Qur'ānic statements, commonly well-known Sunnah, acts commonly done as Sunnah, and every other inerrable conclusive evidence. ${ }^{17}$

This is the brief introduction of historical methods Muslims have been using for determining the historicity of any historical phenomena. It is natural that while applying these principles, one may arrive at a different conclusion than others. Anyhow, rejecting any Muslim historical discourse is not easy. Muslims themselves have been scrutinizing the reported discourses very critically. However, the orientalists rejected many things in the fervor of application of newer methods. 


\section{References and Endnotes}

1 al -Baqara 2: 170; al-Maida 05:104; al Araf 07: 28; al-Anbiya 21:53,54; Al-Shuara 26:74-80; Luqman 31:21; Az-Zukhruf 43:22-24.

2 al- Anaam 06: 138; al-e-Imran 03:94; an-Nisa 04:50.

3 Al-Anaam 06:21,93.

4 Imam Bukhari, Sahih Bukhari, (vol.1) Hadith no. 70-74, which reads as "whoever lies upon me (the Prophet) deliberately, let him take his seat in the Fire".

5 An adjective derived from tawātur convey the meanings of continuous.

6 A person who is skilled in reading the text of the Qur'ān, with all its etiquettes, and rules and regulations.

7 Allāmah means scholar of big stature.

8 Muhammad bin Alial-Shaukani, Irshād al-Fahūl ilā Tahqūq al-Haq Min 'Ilm alŪsūl, (Damascus, Daar al KItab, 1999), 1:128.

9 Muhammad bin Idris Shafi, al-Risālah(Mansura : Dār al-Wafā, 2001), 199.

10 Mannā`al-Qattān, Tārīkh Tashrī al-Islāmī (Beirut : Mu’asasah al-Risālah, 1987), 292.

11 Ibid., 276.

12 An agreement of jurists in a specific era on a sharia ruling.

13 Yūsuf Ibn `Abd Allah Ibn`Abd Al-Barr, Jāmi`Bayān al-`Ilm wa Fadlihi. Edited by Ubaȳ̄ al-Ashbāl al-Zuhayrī.(Cairo: Dār ibn al-Jawzī, 1994), 1:778-779.

14 Muhammad bin Ali al-Shaukān̄̄, Irshād al-Fahūl ilā Tahqīq al-Haq Min `Ilm al$\bar{U} s \bar{u} l$ (Damscus: Dār al-Kitāb, 1999), 1:133.

15 One test is about narrator`s chain in the light of 'ilm al-rijāl and usūl al-Hadith and second is the test of darāyat. Explanation of darāyat is coming ahead.

16 Experts of Hadith

17 Ahmad Ibn `Ali al-Khatībal-Baghdādī, Al-Kifāyah F̄̄ `Im al-Rawayah. Edited by Abū `Abd Allah al-Sūrq̄i and Ibrāhīm Hamadī al-Madn̄̄, (Medina: Al-Maktabah al'Ilmīyah, 2000), 492.

\section{Selected Bibliography}

1. al-Baghdādī, Aḥmad Ibn `Ali al-Khațīb. Al-Kifāyah F̄̄ `Ilm al-Rawayah. Edited by Abū `Abd Allah al-Sūrqī and Ibrāhīm Hamadī al-Madn̄̄. Medina: Al-Maktabah al'Ilmīyah, 2000.

2. al-Bukhari, Muhammad bin Ismail. Sahih al-Bukhari. Edited by Mustafa Deeb alBagha. Berut: Dar ibn Kathir, 1987.

3. al-Qattān, Mannā`. Tārīkh Tashrī al-Islāmī . Berut : Mu'asasah al-Risālah, 1987.

4. al-Shaf $\overline{1}$, Muhammad bin Idrīs. al-Risālah. Mansura : Dār al-Wafā, 2001.

5. al-Shaukān̄̄, Muhammad bin Ali. Irshād al-Fahūl ilā Tahqūq al-Haq Min `Ilm alŪsūl. Damscus: Dār al-Kitāb, 1999.

6. Ibn`Abd Al-Barr, Yūsuf Ibn `Abd Allah. Jāmi`Bayān al-`Ilm wa Fadlihi. Edited by Ubaȳ̄ al-Ashbāl al-Zuhayrī. Cairo: Dār ibn al-Jawzī.1994. 